\title{
Engagement with Death Through Literature: Johannes von Tepl's Plowman (ca. 1400) and Werner Bergengruen's Death in Reval (1941)
}

\author{
Albrecht Classen \\ University of Arizona Department of German Studies 301 LSB Tucson, AZ 85721, USA.
}

How to cite this paper: Albrecht Classen. (2021) Engagement with Death Through Literature: Johannes von Tepl's Plowman (ca. 1400) and Werner Bergengruen's Death in Reval (1941). Journal of Humanities, Arts and Social Science, 5(1), 125-136. DOI: 10.26855/jhass.2021.01.013

Received: March 28, 2021

Accepted: April 25, 2021

Published: May 7, 2021

*Corresponding author: Albrecht Classen, University of Arizona Department of German Studies 301 LSB Tucson, AZ 85721, USA.

Email: aclassen@email.arizona.edu

\begin{abstract}
Literature assumes a huge role in all of human existence, especially with regard to some of the fundamental concerns in life: love, the quest for God, death, and the meaning of all existence. Through the literary lens, those issues have been addressed already throughout the centuries across the world, which strikingly confirms the critical importance of literature per se. This paper discusses the famous literary debate The Plowman by the Czech-German writer Johannes von Tepl (ca. 1400) and the short stories The Death in Reval by Werner Bergengruen (1941) in order to illustrate how much the fictional discourse contributes in a central fashion to the universal efforts to come to terms with such an evanescent phenomenon as death. The paper does not try to carry out a comparative analysis but presents these two works as major contributors to the literary discourse on death. As we can observe, humans have always responded to death with deep emotions, and those are difficult to cope with. Through the literary lens, however, the readers can gain a sensitive distance and learn how to come terms with this phenomenon. We also realize how much medieval literature can actually contribute powerfully to our contemporary concerns, despite a different cultural-mental framework and a remote language.
\end{abstract}

\section{Keywords}

Death in literature, Johannes von Tepl, Werner Bergengruen, late Middle Ages, modern German literature

There are many valid arguments explaining the meaning and relevance of literature, which enjoys at least since the early nineteenth century the credibility of constituting a major academic discipline by itself within the Humanities. Plainly put, it can serve as entertainment, it can engage with historical events within a fictional framework; it can please the ear and mind of the listener/reader; it can teach important moral and ethical lessons; it can serve as a platform to explore values and ideals; it can explain and present the consequences of evil deeds and the impact of goodness; it can relate religious and philosophical teachings; or it can serve as a significant medium to explore ideas, concepts, or notions relevant in human life through a fictional lens. In order to make sense of the following reflections, I refrain from offering a more specific definition of literature, particularly because the pre-modern world embraced a much wider notion of the literary discourse as we consider and pursue it today. All we need to keep in mind is that literature is different from instructional, didactic, religious, scientific, or medical texts and engages with its topic within an imaginary, though not necessarily irrelevant, framework.

Many times, as we may claim, the literary work allows the audience to explore specifically those aspects in all of existence that are ineffable and yet highly relevant, deeply in need of expression in words, images, or sound. Most 
important, as I would like to suggest, a novel, a poem, a play, or a verse narrative facilitates the examination of topics that matter centrally for us all and yet cannot be completely comprehended because we are lacking, as human beings, the intellect for this task. Not surprisingly, many texts in the Christian Bible can also be identified as literary, whether the Song of Songs, the Psalms, or the parables in the New Testament, because they take the audience into an imaginary world of ideas, sentiments, values, and concepts (Gabel \& Wheeler, 1986/1990; Crain, 2010). Those fundamental topics, addressed by poets the world around, can be easily summarized as follows: erotic love; the experience of death; and the quest for God. Based on those three, the search for meaning and relevance in this life and in the beyond is undertaken through literary explorations as well, which provide identity, culture, orientation, and a philosophical frame of mind.

These preliminary thoughts always would need to be taken into consideration whenever we try to come to terms with any literary text from any period and culture across the globe. Literature has always served as a medium to examine, develop, and employ communication as the basic instrument to establish community, and it has helped people throughout time to learn about compassion, collaboration, commitment, then about human values and ideals, and about the meaning of the beginning and the end of our lives (Classen, 2002). As esoteric and secondary literature might be in face of the exigencies of our daily material lives (nourishment, health, work, money), a closer analysis easily proves the central importance of literary texts as profound mirrors of the heart of all matter, spiritually speaking. One of those topics is death, the end of all life for all individuals here on earth.

Almost like a paradox, death cannot be defined other but through negativity: it is non-life, the end of physical existence, the complete loss of what once used to be. At the same time, death assumes a huge role in every culture, whether we think of the normal, natural dying process, or of executions as the extreme form of punishment by the legal system, or whether we think of the consequences of wars and violence. Many of our cultural efforts used to be directed toward handling the dead in a worthy and dignified manner, and in many ways that still holds true today, if we consider all kinds of exorbitant funeral cultures. However, today most cemeteries tend to be located outside of the urban centers because contemporary culture, at least in the west, seems bent on casting a shroud of invisibility on death. Nevertheless, the corpse itself has always been the center of much attention, whether we think of the Egyptian mummies, Greek and Roman mausoleums, Christian burial sites in or near churches, and, today, rather pathetically, funeral homes (Schmitz-Esser, 2014/2016; English trans. by Classen and Carol). Still, the death of a major politician, artist, composer, or philosopher always represents a greater event celebrated mournfully by many survivors, both publicly and privately. Death can also assume a major political function if we think of the various graves of the unknown soldiers in the many wars that have been fought over the last hundreds of years and more. And cemeteries have always served as significant staging grounds for representatives of the government, such as Arlington in Washington, D.C., or the many military cemeteries in the Normandy, established as a consequence of the notorious D-Day, and the end of the Second World War (Marion, 1977; Kerrigan, 1995; Shahshahani, ed., 2009; cf. also for an extensive list of major cemeteries globally, see

https://en.wikipedia.org/wiki/Lists_of_cemeteries\#Germany).

Most people today might not want to think much about death, but this normally constitutes nothing but an automatic defense mechanism without any real success. Death is always in the midst of our lives and virtually defines it by way of removing life itself, both our loved-ones and our enemies. This insight was very prevalent throughout the Middle Ages and the early modern age, but since the late twentieth century, the culture of death seems to have changed, particularly in the West, somehow transforming from being a central issue and icon for society at large into an anathema because we try to ignore old age and death due to the modern obsession with (eternal) youth. The reasons for this development have certainly much to do with capitalistic conditions shaping our lives since youth seems to 'sell' better than old age (Noys, 2005; Vogt, 2020; for an excellent overview, see now https://en.wikipedia.org/wiki/Death_and_culture).

However, by way of the literary discourse poets and writers have consistently tried to come to terms with this phenomenon, the end of our existence, whether in the Middle Ages or in modern times (Classen, ed., 2016). The experience of death normally comes along with a profound sense of pain and loss by the survivors, and for that reason, both music and poetry have intensively engaged with this topic throughout time to provide a sense of completion, harmony, and acceptance of the unavoidable. For instance, to introduce briefly a musical example: "The Requiem in D minor, K. 626, is a requiem mass by Wolfgang Amadeus Mozart (1756-1791). Mozart composed it as part of the Requiem in Vienna in late 1791, but it was unfinished at his death on 5 December the same year. A completed version dated 1792 by Franz Xaver Süssmayr was delivered to Count Franz von Walsegg, who commissioned the piece for a 
requiem service to commemorate the anniversary of his wife's death on 14 February. [https://en.wikipedia.org/wiki/Requiem_(Mozart)]. A literary or artistic work engaged with death does not, of course, overcome or solve death, but it can provide words and images, sounds and thoughts that allow the individual sufferer to come to terms with this phenomenon (Han \& Triplett, ed., 2015; Jernigan, Murphy, \& Wang, ed., 2020; Kenfel \& House, ed., 2020; Bender, 2020). Death is, like time, a constant force in all existence, but humans have always had difficulties accepting its existence, which explains, for instance, the critical role assumed by all religions all over the world, which commonly serve as an organizational and spiritual medium to come to terms with the finite moment in all life and to project a world beyond death, to offer some kind of illumination and a sense of meaning, even with this undefinable moment in life, the end of it.

Philosophical and religious reflections on death serve their own purposes (Wils, 2019), but here I will limit myself to the close examination of the question of how literature has consistently provided crucial expressions about and for this non-existence, death. Since people, old and young, and all genders, are constantly passing away, death experience is automatically one of the consistent themes also in world literature. We would do a great disservice to the younger generation if we did not teach them to think critically about death and all of its implications (Moreman, 2008; Korangy \& Rouhi, ed., 2019). In fact, many of the greatest contributions to world literature are focused, in one way or the other, on the experience of death, such as a result of war, genocide, the Holocaust, murder, or accidents, not to talk about the daily experience of death. The current pandemic COVID-19, with millions of dead in 2020 and 2021, is only one of many stark reminders of the centrality of death, and this at the very current moment.

Death represents such a finite and yet incomprehensible phenomenon that only the poetic word or a musical composition might be able to do justice to it. Since all of human life is framed by birth and death, we have a truly simple but ultimately convincing explanation of and justification for literature right at hand. The poetic freedom opens many avenues toward the critical engagement with this ineffable but certainly constantly present and deeply painful phenomenon.

\section{Two Case Studies: Medieval and Modern}

In order to illustrate the extent to which the issue of death has determined much of medieval and modern culture, here I want to discuss two major works focused essentially on death, one from the early fifteenth century, the other from the mid-twentieth century. These two works were not related to each other and also represent very different genres, but both deeply impacted the history of German literature each on its own at their respective periods and can thus be identified as crucial stepping stones for the further examination of the culture of death through a fictional lens.

The Plowman by Johannes von Tepl constitutes a debate poem involving the Plowman, as the representative of everyman, and Death, whereas Werner Bergengruen's collection of short stories, Der Tod von Reval, approaches death from a variety of narrative perspectives, bringing it close to people's lives without overdramatizing or ridiculing it. As both works illustrate most powerfully, humanity is not to despond over death, but must learn how to cope with it and respect it as an essential aspect of all existence.

\section{Johannes von Tepl: The Late Medieval Voice}

Johannes von Tepl's Der Ackermann aus Böhmen (in its German title), a highly popular dialogue poem from ca. 1400, composed by a German-speaking poet from Saaz, northwest of Prague, today Žatec in the Czech Republic (Classen, 2014), is predicated on a man's recent loss of his wife who had died in her young age, leaving behind her children and her husband. He is deeply upset about her sudden passing away and finds himself in a debate situation, conceived in allegorical terms, accusing Death of being unfair, cruel, unjust, brutal, and miserable overall (Johannes von Saaz, 1969; see now the new edition, Johannes de Tepl Civia Zacensis, 1994; for the English trans., see Haldane, online at: http://www.michaelhaldane.com/Husbandman\%20and\%20Death.pdf; for critical studies, see Classen, 1991; Kiening, 1998; Popović \& Ivan Pfeifer, ed., 2016). The text has survived in eighteen manuscripts, a significant number confirming its high popularity, especially considering that virtually all manuscripts containing this text from the Bohemian areas were burnt or lost otherwise during the Hussite Wars

(https://handschriftencensus.de/search/hss/0/Johannes+von+Tepl). It was also printed a number of times since 1461 (Kiening, 1998).

The two debaters do not speak the same language for a long time, with the Plowman filled with rage, fury, sorrow, sadness, and despondency. Death, by contrast, argues rationally, coldly; he is aloof and domineering, and does not grant his opponent any room because he claims consistently that he is the master of the world, has received his power from God, and is charged with taking all life; otherwise, the world would become overpopulated and hence suffer 
from famine and other severe problems.

Death disrespects the Plowman as an imbecile and fool who is hardly worthy of his attention. For him, all the emotions voiced by his opponent are not worth his consideration, and he regularly dismisses all arguments raised against his actions and his very existence as illogical, unreasonable, and ignorant of the basic facts of life.

Indeed, the Plowman rallies against Death with much fury, anger, frustration, helplessness, despondency; he appeals to God, condemns the working of Death, calls him unfair, unjust, brutal, dismissive, and contemptuous, but Death knows exceedingly well how to ridicule the other, demonstrating regularly that the Plowman does not understand the workings of nature and life, and should simply disregard his own pain. He goes so far as to urge him simply to forget his wife, to marry again, and thus to overcome all of his pain. He is, master of all, ruthless and brutal, not willing to budge one iota, which proves to be increasingly irritating for the Plowman.

Right from the start, the Plowman accuses Death of being an evil person, acting against all laws, ideals, and human values, being an enemy of humankind: "Shameless villain, your evil remembrance live and persist without end; fear and terror never part from you, live wherever you will! I and all humanity wring our hands and scream the hue and cry after you!" (ch. 1). As is to be expected, although this poem is a masterpiece of rhetoric and not an autobiographical reflection, the Plowman is torn apart by his emotions and almost uncontrollably yells at Death, complaining bitterly that all of his happiness has been destroyed because of the loss of his wife:

I used to be bright and merry at every hour; all my days and nights were short and joyful, the one as full of delight, as full of bliss, as the other; my every year was a year of grace. Now I am told: Croak! Remain with dismal thoughts on a withered bough, in darkness and wilting, and howl incessantly! The wind drives me so, I am swimming the surge of the wild sea, the waves have won the upper hand, my anchor holds fast nowhere. Therefore I shall scream without ending: Death, you take my curse! (ch. 3).

Significantly, though the Plowman does not realize that, they both agree on one essential point, the beauty and dignity of the deceased woman. As Death comments:

We performed our act of grace on a respectable, blessed young lady there; her letter was the twelfth. She was virtuous and free from blemish; for We were present at her birth. At that time, Lady Honour sent her a gusseted mantle and garland, in the hands of Lady Fortune. She took the mantle and garland with her, whole, untorn, and untarnished, to the grave. Our witness, and hers, is He who knows all hearts. She was pure of conscience, assiduous, faithful, honest, and supremely gracious to one and all. - Verily, so gentle and constant a nature has seldom come into Our hands. Perhaps this is the one you mean; We know of no other" (ch. 4).

In fact, in the face of death, the deep value of a good marriage is being highlighted, with both men regarding the wife as a most honorable person. Johannes von Tepl thus brings to our attention a new perspective on marriage and women at large, in an explicit turn away from traditional medieval misogyny and misogamy (cf. Classen, 2003; Classen, 2005).

The poet thus indicates that in face of unavoidable death, the husband begins to realize the true value of his wife, and just that causes him his deep pain because he appreciated and loved her so much.

For death, such emotions are of no consequence and value because he is the master over all people. No science, no medical expertise, no political power, no personal preference would be able to sway him; death is the radical, absolute, and unchangeable conclusion of all life:

All those masters who can compel spirits must commit and relinquish their spirit to Us; the necromancers and magicians cannot withstand Us, and their riding on sticks, their riding on goats, helps them nought. The doctors who lengthen the lives of men must come to our shared shore: roots, herbs, ointments, and manifold apothecatical powders cannot help them. If we made account to even the butterflies and the grasshoppers for their species, they would not be satisfied. And if we let people live for the sake of friendship or enmity, of love or sorrow, the whole world would now stretch as Our Empire; every King would have placed his crown on Our head and presented his sceptre to Our hand; the Papal See and the three-crowned mitre would now be in Our power (ch. 6).

In the course of the debate, however, the Plowman begins to mellow his charges against Death, questions him about his origin, properties, purpose, and relevance, although he will never be able fully to understand what death might really mean. Nevertheless, the entire debate turns into a kind of "Trauerarbeit," or a process of coming to terms with grief, which ultimately allows the Plowman to rationalize his painful experience (Classen, 2003). In fact, he calms 
down in the course of the debate, turns his attention away from himself and his emotions, then he inquires about the nature of Death, and argues with him about the relationship between Death and humanity.

However, the Plowman has to accept all the time an enormous degree of mockery and contempt by his opponent, who coldly insists, for instance, "He is foolish who weeps for mortals. Desist! The living to the living, the dead to the dead, as hitherto. Consider your cause more deeply, you fool, before you begin to complain!” (ch. 8). Even though the Plowman tries his best to defend himself, his wife, humanity at large against the working of Death, he is constantly in danger of losing the battle, as painful as this might be. Nothing helps him, his personal appeals to Death, nor his appeals to God, who does not appear until the end of the dialogue poem. In fact, the Plowman is all alone and has to fend for himself without making any inroads into Death's arguments.

As Death unmistakably emphasizes: "Now, when all human generations who have been or are yet to be must pass from being to non-being, how may the Extolled One you mourn enjoy the advantage that she not be done to as all others, and all others not be done to as she? You yourself will not escape Us, although this may be far from your thoughts at present” (ch. 10). The Plowman paints a glorious picture of his wife, giving her the highest praise a woman might ever gain: "Honour, propriety, chastity, generosity, fidelity, moderation, care and modesty always inhabited her house; shamefacedness always bore the mirror of honour before her eyes; God was her gracious protector. He was also gracious and merciful to me for her sake; health, happiness and fortune were mine” (ch. 11). Yet, all that is to no avail, since Death will never be prevented from doing his job. Although he calls Death a murderer, the latter dismisses this charge outright and ridicules the Plowman for his ignorance of the ultimate matters of life.

Almost painfully, Death increasingly undermines his opponent's position, asking him, for instance, what had made his deceased wife so virtuous. If she had been virtuous by herself, he would easily be able to find another woman and marry her. If she had become virtuous through his working, he could count himself among the blessed, being able to educate and transform people (ch. 12). Death also injects a fundamental argument by the late antique philosopher Boethius (d. ca. 524), warning him about the consequence of love which would always follow by sorrow. All worldly forms of happiness, as Boethius had already indicated in his famous Consolation of Philosophy, would be only transitory, and the more one relied on any one of them, the more sorrow would follow:

Wife, child, wealth and all earthly goods must bring some measure of joy at first, and a greater of sorrow at last; and in many places it was the custom for the torturer to ask forgiveness of the tortured. goods must bring some measure of joy at first, and a greater of sorrow at last; all earthly love must turn to sorrow; sorrow is love's end, the end of joy is grief, sadness must follow pleasure, the enjoyment of one's will must end in disaffection - to such an end all living things must run. Learn a little more, if you wish to cackle with wisdom! (ch. 12).

Irony, satire, even sarcasm pervade the entire argument developed by Death, who proves to be a master of rhetoric and most intellectual in the entire debate. He goes so far as to extol the wife who died a good death, not in old age, as a result of a sickness, or with much pain: "He did not die well who desired death; he has lived too long who calls on Us for death; woe and hardship to him who is overloaded with the burden of age: in the midst of wealth he is poor!” (ch. 14).

Moreover, Death identifies himself as the most just tool in God's hands, cutting down everyone without distinction (ch. 16), which the Plowman tries to object to (ch. 17), though ultimately to no avail. In response to our own observation above about the paradoxical nature of death, this ominous force explains this powerfully: "You ask what We are: We are nothing, and yet something. Nothing, because We have neither life, nor being, nor form, and We are no spirit, not visible, not tangible; something, because We are the end of life, the end of existence, the beginning of nullity, a cross between the two. We are a happening that fells all people. Huge giants must fall before Us; all living beings must be transformed by Us” (ch. 16). The Plowman attempts to fight back, accusing Death of bitter injustice: "I saw more lords than servants lying dead. You would pick one from the rest like so many soft pears. Is that how to reap justly? Is that how to judge justly? Is that your scythe cutting straight ahead? Come here, dear children, come here! Let us ride towards, let us sing the praises of, let us offer honour to Death, who judges so justly!” (ch. 17). Nevertheless, all this is useless, as the Plowman finally acknowledges himself (ch. 19), trying to begin with a constructive discussion about the meaning of all life and hence about death, as feeble as he might be to comprehend the powerful force of death.

Unfortunately, this effort to reach out to the opponent fails because Death has only contempt for him and quickly puts him into his own place: "No individual may gainsay that which all humans must suffer. A man shall return what he has borrowed. All humans are strangers on this Earth. They must pass from something to nothing. Every man's life runs along on fast feet: this moment, living; in the turning of a hand, dead. To briefly conclude: every human owes the debt of death and has inherited death. If you weep for your wife's youth, you are wrong to do so; as soon as a human 
has life, so soon is he old enough to die" (ch. 20). In fact, Death goes so far as to warn the Plowman about the downfall of old age and that dying in one's own youth and beauty would actually be a blessing (Classen, ed., 2007).

However, there is also a remarkable turn in the argument. While the Plowman begs Death for advice and help in coming to terms with his personal suffering over the death of his wife (ch. 21), Death rudely rejects him and begins to claim absolute priority over all life, justifying his own existence as the ultimate reason for life to exist:

life is created for the sake of Death. If life were not, We would not be, and Our business were nought; nor would the world order exist. Either you are filled too deeply with sorrow, or unreason is housing inside you. If you are from your reason, then beseech God to grant you rationality! If you are filled with sorrow, however, then stop, let go, and take this on board: man's life on Earth is but a breath of wind! (ch. 22).

Death goes so far as to urge the Plowman to follow Aristotle's teachings to dismiss all joy and hope, and to accept that they are automatically accompanied by grief and sorrow: "Whoever will not drive all love from his heart must bear the presence of grief at all times. Drive the remembrance of love from your heart, from your senses, from your mind, and at once you will be relieved from sorrow!” (ch. 22).

For the Plowman, this negativity cannot stand, and he insists on the prime importance of joy and happiness in this world, otherwise, evilness would replace it and bring all people down. As to his own wife, however, he then insists in the critical need of memory which can overcome the pain of death: "When great, heartfelt love is transformed into great, heartfelt sorrow, who can forget this so soon? That is what evil people do. Good friends think always of one another; distant roads, long years, do not part dear friends. She may be dead to me in body; she is ever living in my mind" (ch. 23). In fact, memory has been identified as an essential hermeneutic aspect in medieval culture, and Johannes von Tepl confirms this profoundly (Willaert, ed. 2004; Althoff \& Fried, ed., 2009; Doležalová, 2010).

Ironically, this deeply humanistic approach to the loss of a loved-one truly riles up Death who suddenly begins to lose his own calm and turns to making slanderous remarks about human life as such. We have to keep in mind that Johannes von Tepl endeavored to develop a masterpiece of rhetorical elegance and skill, and Death's surprising outburst of hostile comments about the human body certainly contributes to this. It is even worth quoting at length:

a human is conceived in sin, nourished with impure, unspeakable feculence in the maternal body, born naked and smeared like a beehive; a mass of refuse, a churn of filth, a dish for worms, a stinkhouse, a repulsive washtub, a rancid carcass, a mildewed crate, a bottomless sack, a perforated pocket, a bellows, a rapacious maw, a reeking flagon of urine, a malodorous pail, a deceptive marionette-show, a loamy robber's den, an insatiably slaking trough, a painted delusion. Let recognise who will: every human created to completion has nine holes in his body; out of all these there flows such repellent filth that nothing could be more impure (ch. 24).

However, this defilement then makes it possible for the Plowman to offer a quick repartee, which constitutes a sort of global rejection of all of medieval theology, particularly Lotario dei Segni's, the later Pope Innocent III's famous De Miseria Condicionis Humanae from ca. 1200, which exerted a huge influence throughout the following centuries, as documented by ca. 672 manuscript copies, a number which barely any other medieval text ever achieved, so Death here represents one of the most important theological arguments characteristic of the entire Middle Ages (Lotario dei Segni, 1978; for the 1855 edition by Eduard Weber, see

https://archive.org/details/decontemptumund00achtgoog). In fact, Death emerges as the exact literary manifestation of Innocent's teaching, but the Plowman can finally seize the opportunity and argue against this highly negative position, insisting, virtually in the vein of an early German-Bohemian Renaissance man, on the absolute beauty and divine origin of the human body, completely in contrast to Death's opinion:

Sir Death, cease your pointless yapping! You sully God's most splendid creation. Angels, devils, imps, and birds of death, all these are spirits under the government of God; man is the most noble, the most skilled, and the most free of all God's works. God formed him in His image, as He Himself proclaimed at the Creation of the World. Where has a workman ever effected so skilled and rich, so masterly and small, a sphere as the human head? Inside it there are artful, wondrous powers, incomprehensible to all spirits. In the eyeball there is the face, the most reliable of witnesses, masterfully worked in the way of a mirror; it reaches the clarity of the heavens. In the ears is the far-reaching sense of hearing, perfectly grated with a thin membrane for the perception and differentiation of a host of sweet sounds. In the nose is the sense of smell, entering and leaving through two holes, purposefully carpentered for the ease and convenience of all sweet and delightful scents. In the mouth are teeth, which grind the body's nourishment every day; also the tongue's thin leaf to pass thoughts between humans; and it holds the pleasurable sense of gustation for every kind of food. And then, in the head, there are thoughts 
coming from the depths of the heart, with which mankind rapidly reaches as far as he wills; with his thoughts, man clambers towards, and even above, the divine. Only man is in possession of reason, the noble treasure. He alone is the delightful form, whose like none but God is able to shape, and in which all skilled works, all art and mastery, are woven with wisdom. Let go, Sir Death! You are the enemy of man: that is why you speak him ill (ch. 25).

Thereupon, Death loses his own temper, and the rational debater then turns to cussing and calumny, rejecting all established and all necromantic sciences, thereby undermining his own previous insistence on logic, reason, and rationality (Classen, 1991). Moreover, Death goes one step further and condemns marriage as the worst possible form of human coexistence (ch. 28), which, however, has no longer any real affect and proves to be a weak defense mechanism, as many other male writers from that time had to realized (Blamires, ed., 1992). The Plowman continues with his own defense, but he cannot push through Death's by then irate and emotional (!) attitude, insisting on his absolute power and authority. He calms down to some extent, but never changes his position, stating resolutely:

All is vanity, a sickness of the soul, as transitory as the day that passed yestereve. They gain this through war and rapine; the greater the possessions, the greater the robbery. They bequeath it to discord and conflict. Oh, mortal man is always in fear, in affliction, in sorrow, in care, in dread, in terror, in days of pain, in days of sickness, in sadness, in mourning, in misery, in grief and in multeity of irritations; and the more worldly wealth a man has, the more annoyances he encounters. And this is the greatest of all, that a human cannot know when, where and how We shall suddenly overfall him and drive him the way of all flesh (ch. 32).

Thereupon, the dialogue comes to its conclusion, with God intervening and giving his judgment as to who won the debate. In reality, as He observes, neither one was fully entitled to pursue their arguments the way they did because the Plowman's happiness was only a loan from God, whereas Death's claim on his authority was flawed since all depends on God: “This one laments what is not his; that one boasts of a power that is not immanent" (ch. 33). As to be expected, however, he grants Death the victory because all life, indeed, has to come to an end. Nevertheless, he then turns to the Plowman and gives him astounding credit for having fought valiantly and defending his claim respectably: "So plaintiff, yours is the honour! And Death, yours is the victory! Every man is obliged to give his life to Death, his body to the earth, and his soul to Us" (ch. 33).

The dialogue then concludes with the Plowman praying for his wife's soul and praising God. His laments have found noble and worthy expression, although the entire text was conceived as a rhetorical exemplum, so to speak. Johannes von Tepl thereby managed to overcome the totally negative approach to human life by the Catholic Church, to give praise to love, marriage, and women, and to express in a highly sophisticated manner the process of coming to terms with death.

The Plowman's woeful mourning resonates throughout the centuries and continues to appeal to us. Death has not let go of his grip on us people, and pain continues to be a burning issue in every individual here on earth. Despite the historical distance (more than six hundred years), this rhetorical exchange constitutes a worthy literary monument dedicated to the human struggle with death (for the latest critical analysis and biographical and philological data, see Classen, 2021).

\section{Werner Bergengruen}

Although originating from a very different background, although drawing from a very different genre, and although having been written more than five hundred years after Der Ackermann aus Böhmen, when we turn to Werner Bergengruen's collection of short stories titled Der Tod von Reval (Bergengruen, 1939; The Death from Reval), we encounter another highly popular literary work in the German language deeply invested in exploring the nature, meaning, and impact of death in all of human life. The purpose here cannot be to engage extensively with this Baltic-German writer (1892-1964), who enjoyed great popularity with his novels, short stories and poems since the 1930s and 1940s, although he was not on the best side of the Nazis and could thus gain great respect in the post-war era.

Dealing with death in these eight narratives which make up the anthology, Bergengruen turned his readers' attention entirely away from the political and military conflicts in Germany at that time, characteristic of his own move into the 'inner exile'. He was a survivor within that terror regime, and continued to publish very popular works even long after the war, and thus he rose to something like an iconic figure of modern German literature. However, since the time of the student revolts since 1968, he was quickly attacked for his curious association and accommodation with the Nazis, heavily criticized for his historicizing and esoteric themes, his strongly Catholic outlook in increa- 
singly secularized modernity, and his quest for a spiritual understanding of human lives.

Thus, his popularity faded quickly since the 1970s, and his name disappeared almost completely from schoolbooks and bookstores. We could almost argue that since ca. 2000, Bergengruen has faded away from public awareness (Classen, 2021, “Werner Bergengruen”; Denkler, 2006; Kroll \& von Voss, 2012; Klapper, 2015; see also the contributions to Dichtung als Kulturvermittlung, 1997; Benzinger, 1983). Nevertheless, Der Tod von Reval was reprinted many times and appeared in new editions as late as 2003 and 2006; it was also translated into numerous languages (for a useful biography and a complete listing of all of his works, including their translations, see https://de.wikipedia.org/wiki/Werner_Bergengruen). The literary society, Werner Bergengruen-Gesellschaft (http://werner-bergengruen-gesellschaft.de/) is committed to the preservation of his memory and the continued study of his works. Significantly, perhaps as a sign of a revival in the interest in Bergengruen, his short story "Der spanische Rosenstock” is about to be republished by Arche-Verlag in Zürich in 2021.

Leaving aside all discussions about the meaning of the author's 'inner exile' during the Nazi regime, his possible collaboration with the authorities, or his major effort to put aside the direct engagement with topical issues of today (racism, gender, environment, immigration, etc.) in favor of the constant quest for a spiritual meaning behind all human life, we can certainly gain valuable insights into the concept about death as worked out through the literary discourse offered by Bergengruen. It appears a bit odd today to consider that the author put together his collection from 1938 to 1939, just before the beginning of the Second World War, and just twenty years after the end of the First World War, as if he intentionally turned the attention away of the horrible political and military developments in Nazi-Germany. Nevertheless, he takes us in his typical melancholic and humorous fashion into the history of the Estonian-German city of Reval, today Tallinn, and presents eight different stories about personal encounters with death, which all prove to be, as the subtitle indicates, highly curious and yet eye-opening as well (I am currently preparing an English translation of a selection of Bergengruen's best short stories for Cambridge Scholars Publishing).

Significantly, he uses two out of three mottos taken from the famous late medieval Reval fresco "Dance of Death" by Bernt Notke in ca. 1470, which set the tone of the entire collection; the first one a two-verse couplet, in English translation: "I look before me and behind me/I feel death all the time around me" repeated in the prologue, but there quoted in the Low German original (Freytag, 1993; for the images and their texts, see online at: https://de.wikipedia.org/wiki/Totentanz\#/media/Datei:Bernt_Notke_Danse_Macabre.jpg).

It would be futile to try to summarize and analyze all eight stories and the prologue and epilogue in the short space of this article. But a few highlights from the prologue and the discussion of one of the stories will suffice to gain a good understanding of how Bergengruen perceived death and tried to relate its evanescent nature despite its constant presence in all of human life. This then allows us both to appreciate better his contribution to world literature and to recognize, through his lens, how much the literary discourse empowers us to come to terms constructively with the ineffable phenomenon of death.

As the narrator emphasizes right at the beginning, a city might have any number of living citizens, the number of the deceased would always far exceed them, especially when we are dealing with old cities, a phenomenon which he identifies as a necropolis (9). The vast majority would live in their graves in churches, and crypts, in churchyards and cemeteries. While the living exist only at this moment, the dead represent the infinity of time and are constant citizens, never going away. The dead have fallen out of time and no longer care about the differences in years, "und siesindin einer großen Gelassenheit" (9; they are in a great serenity). The narrator refers to an epitaph inscribed on one of the graves in Latin, "Parva domus, magna quies" (10; small is the house, great is the peace). The cemetery of Reval has many stories to tell, as the dead are not forgotten and continue to live on through the memory, especially by literary authors.

However, Bergengruen urges his audience not to approach the topic of death with melancholy, but with a certain lightheadedness because the dead all have a story to tell, many of which might provoke laughter. Death should not be regarded as an ominous taboo, but simply as part of all life, as an integrative element, particularly in the Baltic countries, with their short summers and long winters, with the thick fog, the long dusk, early snowfall, and cold temperatures. In that world, as the narrator points out, people drink preferably heavy schnapps or spirits, which makes the interaction with the dead to a much more mundane and familiar entity: "Und mitten in allem Leben sind die Totengegenwärtig" (12; And amidst all life, the dead are present). He emphasizes, in the end, that there would not be any reason to fear death; instead, we should try to become familiar with it, like a friend. This then would make life more livable and acceptable and remove all fear of the imminent end. 
In each tale, the traditional distance between the living and the dead is almost eliminated, and death itself appears as a common feature that does not need to be feared. On the contrary, as “Jakubsons Zuflucht” (Jakubson's Refuge) illustrates, both the living and the dead can accommodate each other quite well without getting into conflict with each other, if they do not even help the respective other. We first hear of an old and wealthy widow, Heydenacker, who, out of extreme miserliness, lives for rent somewhere in the shabby suburb until she dies one day. The other person in this story is a homeless man, Jakubson, who lives by playing some music, by begging, and by entertaining people. One day, he gets into bad company playing cards with them, obviously for money, and he has eventually to run away from them because they believe that he cheated them and are prepared to beat him up badly. Jakubson discovers, in the last second, an open window at ground level, steps in and hides in the dark room, while the evil fellows disappear in the dark. The homeless man discovers several bottles of medical alcohol and happily consumes them completely until he is so drunk and tired that he must find a place to sleep. Only then does he realize that he is in the presence of the dead widow, but her bed is so wide that there is enough room for him for the night. Not afraid of the dead person, Jakubson slips under the blanket next to the old woman and quickly falls asleep, completely carefree.

The next morning, he is discovered by the landlady and the deceased's nephew, who threatens to cause a huge scandal. But Jakubson defends himself humbly, insists that he did not steal anything, did not make any noise, only prayed for the old woman, and, like in a joke, also admits that he had asked her for permission to sleep in the bed with her (85). The debate between the three threatens to erupt in a huge fight, but Jakubson manages to avoid further conflict and disappears quickly, when the nephew is about to lose his temper for good (867).

Then follows the funeral, which begins with a large festive dinner for all guests mourning the deceased. To the surprise of everyone, Jakubson also appears and enjoys all the good food and drink, while the servants are embarrassed and do not know what to do in this situation. The homeless man copes well, however, acts here as if he were one of the invited guests, and subsequently listens to the minister's sermon, and disappears afterward without being noticed by anyone.

But the account does not come to a closure yet. Instead, the narrator also relates the actual interment, which runs all smoothly, without too many emotions, obviously because the widow had reached a high age, had lived remotely from her relatives, and had not demonstrated any particular kind of social responsibility or kindness to her family members (90).

Just when the entire funeral is about to be completed, Jakubson appears again, approaches the grave, throws three handfuls of earth into the grave and says, clearly audible for all present: “'Auf Wiedersehen, gnädige Frau. Und ich bedanke michauch"” (91; “Good bye, my lady. And I thank you as well). Subsequently, he pretends as if he has tears to wipe from his eyes, and disappears, but he is still heard from the distance, whistling all kinds of melodies as if nothing had happened.

In a way, Jakubson expressed more authentic feeling with his gratitude than all the others, but the entire situation could have easily turned into a huge scandal. However, the homeless man demonstrated wit, humbleness, and skill, and subsequently manages to escape from a significant danger for his freedom. As much as the nephew seems justified to talk about corpse desecration, in reality, as the narrator indicates, he had only interacted with the dead body as was basically necessary for him. Jakubson did not demonstrate any fear of death and regarded himself as entitled to the alcohol and the rest in the bed next to the dead-certainly a near-grotesque situation, and yet also proof that in Reval the living and the dead could coexist harmoniously and profit from the respective situation without hurting the other person's reputation.

The case of "Kaddri in der Wake" (115-34; Katie in the Fishing Hole) adds a more somber tone, presenting an unhappily married couple. Although Tönno is a good eel catcher who also knows well how to smoke them, which could easily make him rich, his wife Kaddri wastes much of their money through her uninhibited desire to go drinking and flirting with other men. The story begins with Tönno noticing one winter night that he hardly catches any eel in contrast to earlier times, without having any explanation for this. At the same time, Kaddri does not come home, not even after two days during which her husband looks for her everywhere. When he has returned to his hut and then goes out to check his ice hole, he suddenly realizes that his eel hook is enormously heavy, more than ever before. With great effort, he manages to pull it out and discovers that his dead wife is hanging on the large hook. She had stolen many of his eels and had tried to do that again one more time, but in her drunken stupor, she had fallen into the hole and had drowned.

Tönno is shocked to realize that her entire body is covered with eels that are eating of her flesh. The fisherman then gets into action, collects all the eels, and throws the corpse back into the water, considering this as the justified compensation for years of suffering from his wife. As the narrator emphasizes, he is a poor man and has been kept so 
poor because of Kaddi's thievery, alcoholism, and lustfulness (120-21). Tönno regards it as divine retribution that she herself now has turned into his bait, and for the next few days he earns much money selling the huge number of eels in Reval.

Finally, however, the local bailiff Maddis catches him and threatens to prosecute him because the fisherman committed something wrong, though there is no clear indication of what the actual crime might be. Everyone knows of Kaddi's bad behavior, and both men agree that she must have drowned in a state of alcoholic drunkenness. Maddis does not want to hurt the poor fisherman, but he forces him to pay a fine for his failure to report his wife's death, and this in the form of eels. But since Tönno is so poor, he allows him to use Kaddi for two more days as bait to avoid his financial ruin (130-31), and then the bailiff leaves him, content that they have solved the issue so amenably.

At first, the fisherman is quite stunned, but suddenly he remembers that Kaddi had been his wife, that they had married happily nine years ago, that they had enjoyed a good time together until things had turned bad for him, above all. Completely changing his mind, Tönno carries the corpse home and covers her with a blanket, "denn es sollte kein Auge mehr auf den verwüsteten und zerfressenen Körper fallen, der einmal seine Freude gewesen war" (132; because no one should ever cast an eye on the destroyed and eaten-up body which once had been his joy). Instead of using her as bait for more eels, he prepares a splendid funeral, as if he still were in love with his wife.

There would be much more to say about this and the other stories about death in Bergengruen's collection. The critical issue, however, here proves to be the realization that death is not an alien force, a real threat, a murderer, or some unspeakable danger. Instead, as we read in the epilogue,

Der Tod ist ein großer Trost. Er macht, daß niemand sich zu fürchten braucht. Wir werden einmal unsern Tod sterben, ein jeder in seiner Art und zu seiner Stunde; darum darf unser Herz nicht schwer sein. Wer in Reval war, der wird den Tod nicht mehr fürchten mögen. Und wir wollen den Tod liebhaben, gleichwie wir die Stadt liebhaben. (175).

[Death is a great consolation. It brings it about that no one has to be afraid. We will die our death one day, each person in his/her own way and own hour; for that reason, our heart must not become heavy. He who has been in Reval, will no longer want to fear death. And we want to like death, just as we like the city.]

\section{Conclusion}

Both Johannes von Tepl and Werner Bergengruen offered significant approaches to death, each in his own way, very different and yet in a familiarizing way. While the former illustrated through the debate how the mourner can come to terms with death and fight, in that process, for his wife, his marriage, and the dignity of all women, the latter presented numerous cases of death and the way how the living interacted with it peacefully, unencumbered, constructively, and accepting. The two narratives demonstrate powerfully how much literature can serve exceedingly well how to come to terms with the ineffable, constantly present force of death in an amenable, harmonious, and constructive manner. Death is not an enemy, but a friend or a partner in the universal process of life, as much as the Plowman argues against him acrimoniously for most of the debate.

Significantly, in the end, God grants the Plowman honor for his rhetorical efforts, which redeems him after all in all of his desperation and deep longing for his deceased wife. In Bergengruen's stories, death is a regular factor of and in life and does not have to be feared because it is everywhere. As the author insightfully confirms, all people are mortal, feeble, and temporary, but this does not have to mean that hence love, friendship, or happiness would have to be forgone. As both works clearly indicate, life and death are intimately intertwined and form part of the same universal phenomenon, human existence.

There seems to be hardly any other medium to come to terms with the end of life as effectively as poetry and other fiction. Here we grasp an enormously potent channel to comprehend deeply a most impactful force, for which we have hardly any concreteor specific words to deal with it, except when we resort to the literary discourse. The pain, the sorrow, the personal struggle, and the effort to become familiar with death out of deep respect for love and life finds its excellent expression in these fictional works. Intriguingly, as we can now realize, if we want to gain a complex grasp of such a global issue as death (or love, God, meaning of life, etc.), it proves to be highly useful to combine textual data from the Middle Ages with those from modernity.

\section{References}

Althoff, Gerd and Johannes Fried, ed. (2009). Medieval Concepts of the Past: Ritual, Memory, Historiography. Publica- 
tions of the German Historical Institute, 9. Washington, DC, and Cambridge: Cambridge University Press.

Bender, Jacob L. (2020). Modern Death in Irish and Latin American Literature. Cham: Springer International Publishing.

Benzinger, Hans. (1950/1983). Werner Bergengruen: Weg und Werk. 4thed. Bern: Francke.

Bergengruen, Werner. (1956). Der Tod von Reval: Kuriose Geschichten aus einer alten Stadt. Frankfurt a. M. and Hamburg: Fischer Bücherei.

Blamires, Alcuin, with Karen Pratt and C. W. Marx, ed. (1992). Woman Defamed and Woman Defended: An Anthology of Medieval Texts. Oxford: Oxford University Press.

Classen, Albrecht. (1991). Der Ackermann aus Böhmen-ein literarisches Zeugnis aus einer Schwellenzeit: Mittelalterliches Streitgespräch oder Dokument des neuzeitlichen Bewußtseins? Zeitschrift für deutsche Philologie 110.3: 348-73.

Classen, Albrecht, ed. (2007). Old Age in the Middle Ages and the Renaissance: Interdisciplinary Approaches to a Neglected Topic. Fundamentals of Medieval and Early Modern Culture, 2. Berlin and New York: Walter de Gruyter.

Classen, Albrecht. (2002). Verzweiflung und Hoffnung. Die Suche nach der kommunikativen Gemeinschaft in der deutschen Literatur des Mittelalters. Beihefte zur Mediaevistik, 1. Frankfurt a. M., Berlin, et al.: Peter Lang.

Classen, Albrecht. (2003). Death Rituals and Manhood in the Middle High German Poems The Lament, Johannes von Tepl's The Plowman, and Heinrich Wittenwiler's Ring, in Grief and Gender: 700-1700. Ed. by Jennifer C. Vaught (33-47). New York: Palgrave.

Classen, Albrecht. (2005). Der Liebes- und Ehediskurs vom hohen Mittelalter bis zum frühen 17. Jahrhundert. Volksliedstudien, 5. Münster, New York, Munich, and Berlin: Waxmann.

Classen, Albrecht. (2014). Mental and Physical Health, Spirituality and Religion in the Middle Ages and Early Modern Age: Medieval Answers for Our Future? With Special Emphasis on Spiritual Healing Through Narratives of Mourning: Johannes of Tepl and Christine de Pizan, Mental Health, Spirituality, and Religion in the Middle Ages and Early Modern Age, ed. Albrecht Classen. Fundamentals of Medieval and Early Modern Culture, 15 (1-154). Berlin and Boston: Walter de Gruyter.

Classen, Albrecht, ed. (2016). Death in the Middle Ages and Early Modern Times: The Material and Spiritual Conditions of the Culture of Death. Fundamentals of Medieval and Early Modern Culture, 16 (Berlin and Boston: Walter de Gruyter).

Classen, Albrecht. (2021a). Johannes von Tepl. Literary Encyclopedia, online. Feb. 4, 2021. https://www.litencyc.com/php/speople.php?rec=true\&UID=5805.

Classen, Albrecht. (2021b). Werner Bergengruen, Literary Encyclopedia; online, Jan. 25, 2021, https://www.litencyc.com/php/speople.php?rec=true\&UID=14708.

Crain, Jeanie C. (2010). Reading the Bible as Literature: An Introduction. Cambridge: Polity Press.

Denkler, Horst. (2006). Werkruinen, Lebenstrümmer: literarische Spuren der “verlorenen Generation” des Dritten Reiches Untersuchungen zur deutschen Literaturgeschichte, 127. Tübingen: Max Niemeyer.

Dichtung als Kulturvermittlung: der Schriftsteller Werner Bergengruen. (1997). Die Deutschen und ihre Nachbarn im Osten. Beiträge für Unterricht und Weiterbildung. Filderstadt: Winmann.

Doležalová, Lucie. (2010). The Making of Memory in the Middle Ages. Later Medieval Europe, 4. Leiden and Boston: Brill, 2010.

Frank Willaert, ed. (2004). Medieval Memory: Image and Text. Textes et études du MoyenÂge 27. Turnhout: Brepols.

Freytag, Hartmut, ed. (1993). Der Totentanz der Marienkirche in Lübeck und der Nikolaikirche in Reval (Tallinn): Edition, Kommentar, Interpretation, Rezeption, ed. Hartmut Freytag. Niederdeutsche Studien, 39. Cologne, Weimar, and Vienna: Böhlau.

Gabel, John B. and Charles B. Wheeler. (1986/1990). The Bible as Literature: An Introduction. 2nd ed. New York: Oxford University Press.

Han, John J. and C. Clark Triplett, ed. (2015). The Final Crossing: Death and Dying in Literature. New York: Peter Lang.

Jernigan, Daniel K., Neil Murphy, and W. Michelle Wang, ed. (2020). Routledge Companion to Death and Literature. Routledge Companions to Literature. New York and London: Routledge. 
Johannes de Tepl Civia Zacensis. (1994). Epistola cum Libelloackerman und Das büchleinackerman. Nach der Freiburger Hs. 163 und der Stuttgarter Hs. HB X 23. Vol. 1: Text und Übersetzung, ed. Karl Bertau. Vol. 2: Karl Bertau, Untersuchungen. Berlin and New York: Walter de Gruyter.

Johannes von Saaz. (1969). Der Ackermann aus Böhmen, ed. Günther Jungbluth. Vol. I. Germanische Bibliothek, 4. Series: Texte. Heidelberg: Winter.

Kenfel, Veljka Ruzicka and Juliane House, ed. (2020). The Death in Children's Literature and Cinema, and Its Translation. Kinder- und Jugendkultur, -literatur und -medien, 123. Berlin, Bern, and Vienna: Peter Lang.

Kerrigan, Michael. (1995). Who Lies Where-A Guide to Famous Graves. London: Fourth Estate.

Kiening, Christian. (1998). Schwierige Moderne: Der 'Ackermann' des Johannes von Tepl und die Ambiguität historischen Wandels. Münchener Texte und Untersuchungen zur deutschen Literatur des Mittelalters, 113. Tübingen: Max Niemeyer.

Klapper, John. (2015). Nonconformist Writing in Nazi Germany: The Literature of Inner Emigration. Studies in German Literature, Linguistics, and Culture. Rochester, NY: Camden House.

Korangy, Alireza and Leyla Rouhi, ed. (2019). The "Other” Martyrs: Women and the Poetics of Sexuality, Sacrifice, and Death in World Literatures. Martyrdom and Literature, 1. Wiesbaden: Harrassowitz.

Kroll, Frank-Lothar and Rüdiger von Voss. (2012). Schriftsteller und Widerstand: Facetten und Probleme der "Inneren Emigration”. Göttingen: Wallstein Verlag.

Lotario dei Segni (Pope Innocent III). (1978). De Miseria Condicion is Humane: Book of the Misery of the Human Condition, ed. Robert E. Lewis. The Chaucer Library. Athens, GA: University of Georgia Press.

Marion, John Francis. (1977). Famous and Curious Cemeteries: A Pictorial, Historical, and Anecdotal View of American and European Cemeteries and the Famous and Infamous People Who Are Buried There. New York: Crown.

Moreman, Christopher M., ed. (2008). Teaching Death and Dying. Teaching Religious Studies Series. Oxford: Oxford University Press.

Noys, Benjamin. (2005). The Culture of Death. Oxford: Berg.

Popović, Michael and Ivan Pfeifer, ed. (2016). Der Ackermann aus Böhmen: Materialien einer Deutsch-Tschechischen Konferenz über den Tod und das Sterben, Saaz, 14.-15.10.2006 = Oráč z Čech. 2nd expanded ed. Studien des Hauses Königstein, 6. Bad Schussenried: Gerhard Hess Verlag.

Schmitz-Esser, Romedio. (2016). Der Leichnam im Mittelalter: Einbalsamierung, Verbrennung und die kulturelle Konstruktion des toten Körpers. Mittelalter-Forschungen, 48. Sec. Unchanged ed. Ostfildern: Jan Thorbecke Verlag. Trans. by Albrecht Classen and Carolin Radtke. London: Harvey Miller, 2020.

Shahshahani, Soheila, ed. (2009). Cities of Pilgrimage. IUAES Series, 4. Berlin and Münster: LIT.

Snowden, Frank M. (2019). Epidemics and Society: From the Black Death to the Present. New Haven, CT: Yale University Press.

Vogt, Katharina. (2020). Sterbeorte: über eine neue Sichtbarkeit des Sterbens in der Architektur. Architekturen, 52. Bielefeld: transcript.

Wils, Jean-Pierre. (2019). Das Nachleben der Toten: Philosophie auf der Grenze. Paderborn: mentis Verlag. 